\title{
OVERSOWING GRASSES ON SUNNY AND SHADY FACES
}

\author{
J. G. H White, G. Mejer and R. H. M. Langer \\ Plant Science Department, Lincoln College
}

\section{Summary}

Eight grasses were oversown on steep north and south aspects at Hunua, North Canterbury, either initially with clovers or three years after oversowing clovers. On the north aspect, cocksfoot established and persisted best but ryegrasses were superior on the south aspect. Here the later sowing was much superior, as by then the original dense ccver had disappeared, but on the north aspect time of grass introduction made little difference. Clover introduction resulted in a threefold increase in dry matter production on the south aspect, which produced double that of the north aspect. Ryegrasses raised yields still further, but depressed resident grass production.

\section{INTRODUCTION}

IT IS COMmon PRACTICE when oversowing hill country in the South Island to add grasses such as cocksfoot or ryegrass to the clover mixture. The main reasons for this are, first, to introduce grasses in situations where few or no grasses exist, for example, after scrub or fern; and, secondly, to introduce species which will outyield those grasses already present, particularly during the cool season. Doubts as to the wisdom of oversowing grasses are sometimes expressed, for the following reasons:

(1) Grasses are more difficult to establish than clovers and failure often occurs.

(2) Even if initial establishment is good, survival and production may be limited by low soil fertility or incorrect grazing management.

(3) After legumes are introduced, production of resident grasses such as browntop, Yorkshire fog, Chewings fescue or sweet vernal may be surprisingly good.

Cullen (1959) advocates the inclusion of ryegrass and cocksfoot in all oversowing mixtures, even if low seeding rates are used. He maintains that, although little may be seen of these grasses for several years, they provide a nucleus which will become an important constituent of the sward once fertility is raised. On the 
other hand, from a series of grass introduction trials at Broken River in North Canterbury, O'Connor (1963) concluded that it is not economic to spend large sums 'of money on grass introduction if soil fertility is not already or concurrently built up to high levels.

Evidence varies on the stage of development at which grasses should be introduced and which species should be chosen. Should they be sown with the clovers when soil fertility is low but when competition from existing vegetation is at a minimum? Or is it better to wait for several years after clovers have been introduced, when soil fertility is higher, but when increased competition from the more vigorous resident vegetation may occur? Cullen (1966) found that in bracken country near Te Anau, where little competition existed, cocksfoot, timothy and crested dogstail established well when sown with clovers, in spite of the fact that they were small and contributed little dry matter for 2 or 3 years until the soil nitrogen status improved. Douglas (1966) was also successful in establishing cocksfoot in unimproved bracken, scabweed and hard tussock in Central Otago. In contrast, O'Connor (1963) obtained good establishment of cocksfoot oversown into dense hard tussock at Broken River only when nitrogen levels were high, while in the North Island. Suckling (1959) at Te Awa had much greater success when ryegrass was introduced after 5 years' improvement followed by heavy autumn stocking than when it was introduced initially into dense browntop (Agrostis tenuis).

In 1966, Lincoln College purchased "Hunua", a dry North Canterbury hill country property near Waikari, with the aim of developing it by oversowing and topdressing. Because of the varying evidence available on the value of introduced grasses and the best stage of development to introduce them, a series of trials was commenced by the Plant Science Department to evaluate oversowing of grasses in this environment.

\section{EXPERIMENTAL}

Two adjacent steep slopes, at $500 \mathrm{~m}$ altitude, and typical of large areas of low-rainfall North Canterbury hill country were chosen for the trial. The climate is dominated by strong prevailing north-west winds. Mean annual rainfall is $575 \mathrm{~mm}$ at Hunua homestead but is probably slightly higher at the trial site. The two slopes, with north and south aspects, were in marked contrast. On the north or sunny aspect there is more wind, evapotranspiration is higher, and the soils are drier for long periods, 
Active pasture growth is restricted to spring and autumn. On the south or shady aspect, the climate is cooler, more humid, and the soil moist for a longer period. Pasture growth continues further into the summer. This has resulted in big differences in indigenous vegetation (Table 1). The sunny slope is dominated by species of danthonia (Notodanthonia); there is little tussock and much bare ground. On the shady slope, danthonia is almost completely absent, and is replaced by Chewings fescue (Festuca rubra ssp. commutata), sweet vernal (Anthoxanfhum odoratum), and Yorkshire fog (Holcus lanatus), with much moss, no bare ground, and a considerable amount of hard tussock (Festuca novaezelandiae).

\section{TABLE 1: BOTANICAL COMPOSITION BEFORE AND AFTER INTRODUCTION OF CLOVERS \\ (Total hits $/ 100$ points, November 1970)}

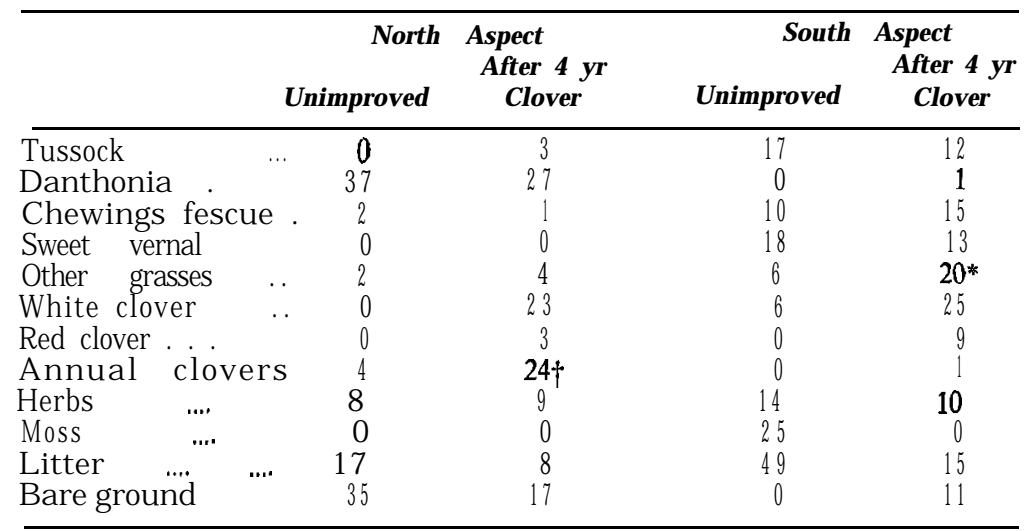

*Mainly Yorkshire fog and browntop.

†Mainly haresfoot trefoil (Trifolium arvense) and striated clover (T. striatum).

The soil on both slopes is a steepland yellow-grey earth of the Haldon set. The soil $\mathrm{pH}$ is 6.1 on the north and 5.6 on the south aspect. Adjacent trials conducted by A. F. R. Adams (pers. corm-n.) showed that the main nutrient deficiency is sulphur with a small response to phosphorus.

\section{Trial Design}

The main trial was designed to measure establishment of eight grasses on each aspect, either sown initially with the clovers in 
1966 or introduced in 1969 after clovers had been growing for three years. The cultivars listed in Table 2 were broadcast on August 4, 1966, in plots measuring $2.7 \times 9 \mathrm{~m}$, replicated three times. No special grazing or other pretreatment was given to the area before sowing. At the same time, $3.3 \mathrm{~kg} / \mathrm{ha}$ each of inoculated white (Trifolium repens), red (T. pratense) and Alsike (T. hybridum) clovers were broadcast on all plots, and on an adjacent area for the later grass sowings. All plots received $500 \mathrm{~kg} / \mathrm{ha}$ molybdic superphosphate initially, and $250 \mathrm{~kg} / \mathrm{ha}$ of superphosphate annually thereafter.

Both aspects were rotationally grazed with sheep at 120 /ha for 2 or 3 days, at intervals of about 8 weeks. commencing three months after sowing.

TABLE 2: GRASS CULTIVARS AND RATES OF SOWING, AUGUST, 1966

\begin{tabular}{|c|c|c|}
\hline Species & Cultivar & $\begin{array}{c}\text { Rate } \\
(k g / h a)\end{array}$ \\
\hline $\begin{array}{l}\text { Ryegrass (Lolium perenne) } \\
\text { Ryegrass ( } \mathrm{L} \text {. multiflorum } \times \mathrm{L} \text {. } \\
\text { perenne) } \\
\text { Cocksfoot (Dactylis glomerata) } \\
\text { Cocksfoot } \\
\text { Cocksfoot } \\
\text { Tall fescue (Festuca arundinacea) } \\
\text { Prairie grass (Bromus unioloides) } \\
\text { Yorkshire fog (Holcus lanatus) }\end{array}$ & $\begin{array}{l}\text { Grasslands Ruanui } \\
\\
\text { Grasslands Manawa } \\
\text { Grasslands A panui } \\
\text { A berystwyth S26 } \\
\text { Aberystwyth S345 } \\
\text { Aberystwyth S170 } \\
\text { Butts (Crawford, 1960) } \\
\text { Massey }\end{array}$ & $\begin{array}{r}6.7 \\
3.3 \\
3.3 \\
3.3 \\
6.7 \\
13.3 \\
13.3\end{array}$ \\
\hline
\end{tabular}

The later sowings were carried out on April 15, 1969, following hard grazing of the area in March. The change to April sowing was made because of the greater success that can be achieved in suppressing vigorous resident vegetation in autumn, following a summer drought. Of the eight grasses sown in 1966, only Ruanui and Manawa ryegrass, Apanui cocksfoot and Butts prairie grass were chosen as these were the cultivars showing promise. In addition, Currie cocksfoot, a winter-active selection from Western Australia, was sown.

Establishment was measured six months from each sowing by counting all seedlings in 10 randomly-sited $0.093 \mathrm{~m}^{2}$ quadrats. At this time ten seedlings per plot were marked with plastic-coated wire for survival studies over the next two years.

Rainfall at Hunua homestead was $64 \mathrm{~mm}$ in August 1966 followed by a dry September and a below-average total of $504 \mathrm{~mm}$ 
in 1967. Dry conditions occurred again in 1969, with $432 \mathrm{~mm}$ rain, although $56 \mathrm{~mm}$ were recorded in April, the month of sowing.

\section{RESULTS AND DISCUSSION}

Table 3 shows the establishment of the four most successful grasses in relation to stage of development. On the north aspect, initial sowings were slightly better than after three years oh clover, but this may have been due to different month of sowing. Ruanui and Manawa ryegrass and Apanui cocksfoot all established well, but single plant studies showed that cocksfoot survived summer droughts better than the ryegrasses. The establishment and survival of S26 and S345 cocksfoots were similar to Apanui. Currie cocksfoot established well and produced much better than Apanui in the cool season. Prairie grass established well but summer droughts caused high mortality. Tall fescue and Yorkshire fog established poorly and few plants could be found. With all species, survival within each plot was better on less steep slopes and in hollows, and on the sheltered side of tussocks or matagouri.

TABLE 3: ESTABLISHMENT OF GRASSES IN RELATION TO STAGE OF IMPROVEMENT

(plants $/ \mathrm{m}^{2}$ six months after sowing)

\begin{tabular}{lcccc}
\hline Grass Species & $\begin{array}{c}\text { North } \\
\text { With } \\
\text { Clover }\end{array}$ & $\begin{array}{c}\text { Aspect } \\
\text { After 3 yr } \\
\text { Clover }\end{array}$ & $\begin{array}{c}\text { South } \\
\text { With } \\
\text { Clover }\end{array}$ & $\begin{array}{c}\text { Aspect } \\
\text { After 3 yr } \\
\text { Clover }\end{array}$ \\
\hline Ruanui ryegrass & $9.0 \mathrm{a}^{*}$ & $4.7 \mathrm{a}$ & $1.1 \mathrm{a}$ & $21.3 \mathrm{ab}^{*}$ \\
Manawa ryegrass & $11.3 \mathrm{a}$ & $5.7 \mathrm{a}$ & $0.4 \mathrm{~b}$ & $32.7 \mathrm{a}$ \\
Apanui cocksfoot & $12.7 \mathrm{a}$ & $5.7 \mathrm{a}$ & $0.1 \mathrm{~b}$ & $1.3 \mathrm{c}$ \\
Butts prairie grass & $1.0 \mathrm{~b}$ & $3.7 \mathrm{a}$ & $0.0 \mathrm{~b}$ & $6.3 \mathrm{bc}$
\end{tabular}

Figures sharing the same letter in a column do not differ significantly at the $5 \%$ level of significance.

*Test applied after transformation of data to $\log (x+1)$.

On the south aspect, establishment of all species of grasses was extremely poor at the initial sowing, although clover establishment was very good. All grasses established better when sown three years later, particularly the ryegrasses, where a high population survived and grew vigorously. The. poor establishment of the cocksfoot is difficult to explain but could have been due to slow germination, low seedling vigour, and increased death during heavy winter frosts. 
The marked superiority of the later sowing of grasses on the south aspect was largely due to disappearance of a dense moss and litter cover and the development of much bare ground (Table 1). The rapid decline in moss seemed to be associated particularly with topdressing, introduction of clover, and improvement in fertility. Trampling alone was not a major contributing factor as unimproved areas adjacent to the plots and receiving similar levels of trampling still retained their moss cover.

\section{PASTURE PRODUCTION}

The vigorous ryegrass growth on the south slope prompted the measurement of dry matter production during the 1970-1 season. Yields from the 1969 sowings of Ruanui and Manawa ryegrass on the south slope were compared with plots on both aspects where clover alone had been introduced. In addition, production from unimproved areas beside the plots was also measured. Growth of introduced grasses on the north aspect was insufficient to warrant measurements being taken. Winter $(22 / 9 / 70)$, spring $(9 / 11 / 70)$, summer $(3 / 2 / 71)$ and autumn $(10 / 6 / 71)$ harvests were made, with 10 randomly located $0.093 \mathrm{~m}^{2}$ quadrats per plot cut at $1 \mathrm{~cm}$ height at each harvest. Each aspect was grazed for 2 or 3 days immediately after cutting. Total yields for the season are given in Table 4.

In the unimproved state, production on both sunny and shady aspects was similar, but four years after introduction of clover

TABLE 4: ANNUAL PASTURE DRY MATTER YIELDS, 1970-1, FOLLOWING INTRODUCTION OF RYEGRASS IN APRIL, $1969(\mathrm{~kg} / \mathrm{ha})$

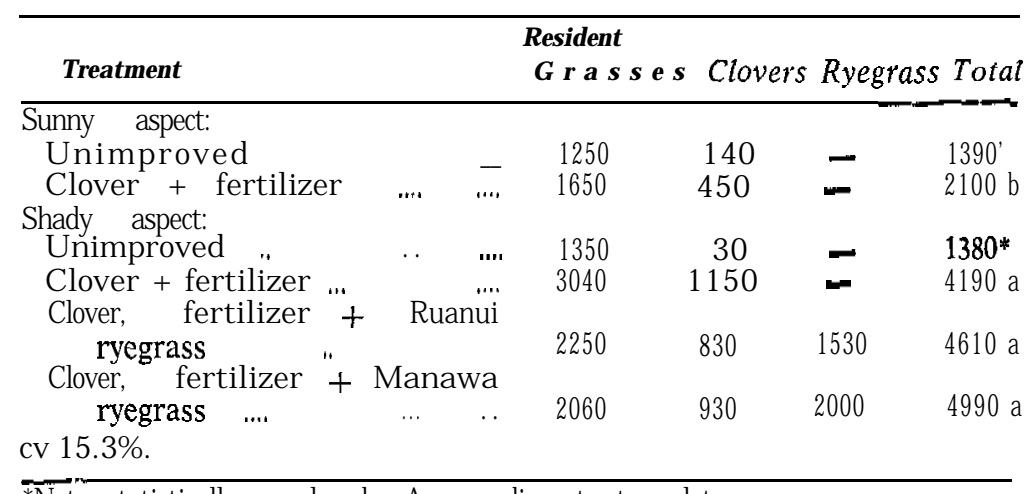

* Not statistically analysed. Area adjacent to plots. 
it had increased $50 \%$ on the sunny slope and threefold on the shady slope. Growth of white clover and the resident grasses, Chewings fescue and sweet vernal, was particularly good on the south slope.

Introduction of ryegrasses increased yield over those plots where no grass was introduced although this was not significant because of site variability. In these plots more than one-third of the total dry matter was from ryegrass which depressed both resident grass and clover production. Ryegrass plots yielded higher than those with ryegrass at all four cuts, but there was no indication from the September cut that the advantage was greater during the cool season.

\section{GENERAL DISCUSSION AND CONCLUSIONS}

The results of this trial when examined together with those of other workers on grass introduction suggest that the following principle could be adopted when oversowing grasses in relation to stage of improvement. Where little competition exists, the best method is likely to be to sow with the clovers. But where ground cover is dense and competition considerable (e.g., vigorous browntop, thick moss, no bare ground), later grass sowings may be superior; soil fertility is built up, and, if competition can be reduced by heavy stocking, rapid establishment and growth of introduced grasses will occur. Therefore, on the sunny aspects of North Canterbury hill country grasses should be introduced with the clovers, whereas on shady faces there would seem to be definite advantages in delaying the sowing for about three years after iegume introduction. The results show that cocksfoot is best for sunny country and that Currie looks promising as a more coolseason-active variety than Apanui. On shady slopes, where ryegrass is superior, a perennial cultivar is likely to be best because of its persistence.

Following improvement, production on the shady face was double that from the sunny. These results support those of Radcliffe (1971) who obtained similar results on Canterbury hill country at Coopers Creek and Geraldine. In dry hill country with rainfall $<1000 \mathrm{~mm}$ it would seem to be a sound management procedure to develop shady aspects first, and fence them separately to obtain optimum grazing control.

The question of whether or not it is worth while to oversow grasses when developing hill country is still largely unresolved. The results at Hunua show that some indigenous grasses can be 
quite high producing, given improved soil fertility. As large sums of money are spent by farmers on grass seed for oversowing hill country, it is surprising to find that there are virtually no published results of the effects of oversown grasses on dry matter production of hill swards. The results suggest that ryegrass may well increase dry matter yields on shady faces of Hunua. But as this work was carried out in a small enclosure the advantage has yet to be established on a large block where stock management is more difficult and increases in soil fertility may be slower. Now that the factors controlling establishment of grasses on hill country are fairly well known, it is time that effects of oversown grasses on dry matter yields are accurately documented for this type of country. Only when this is done will farmers know if they are spending their money on grass seed wisely or not.

\section{ACKNOWLEDGEMENTS}

The authors thank R. B. F. Moir for valuable assistance in the field, S. Cartridge, Hunua farm manager, for grazing control, and the Tussock Grassland and Mountain Lands Institute for financial assistance.

\section{REFERENCES}

Crawford, W. R., 1960: N.Z. Jl Agric., 100: 357-9.

Cullen, N. A., 1966: N.Z. Il agric. Res., 9: 363-74. 1969: Proc. N.Z. Grassid Ass., 31: 110-6.

Douglas, J. A., 1966: Proc. N.Z. Grassld Ass., 28: 8695.

O'Connor, K. F., 1963: Tussock Grassld Mount. Lands Rev., 5: $20-4$.

Radcliffe, J. E., 1971: Proc. N.Z. Grassld Ass., 33; 91-104.

Suckling, F. E. T., 1959: N.Z. $J l$ agric. Res., 2: 153-64, 488-543. 